\title{
IAMJ
}

INTERNATIONAL

AYURVEDIC

MEDICAL JOURNAL

ISSN: 23205091

Impact Factor: 5.34

Research Article

Impact Factor. 5.34

\section{ANALYTICAL STUDY OF SHATAHWADI GHRITA}

\section{$\underline{\text { Renu Prasad }}^{1}, \underline{\text { Gunjan Sharma }}^{2}, \underline{\text { Radhika Menon }}^{3},{\underline{\text { Aditi }^{4}}}^{4}$}

${ }^{1}$ Associate Professor, ${ }^{2}$ Professor and HOD, ${ }^{3} \mathrm{M}$ D Scholar, ${ }^{4}$ Assistant Professor

PG Dept of Shalakya Tantra, Rishikul Campus, U.A.U, Haridwar, Uttarakhand, India

Corresponding Author: radhuramuveluthen@gmail.com

https://doi.org/10.46607/iamj1308092020

(Published online: September 2020)

Open Access

(C) International Ayurvedic Medical Journal, India 2020

Article Received: 26/08/2020 - Peer Reviewed: 08/09/2020 - Accepted for Publication: 08/09/2020

D) Check for updates

\section{ABSTRACT}

Shatahwadi ghrita is an Ayurvedic formulation mentioned in Ashtanga hridaya in the management of Timira. The main contents of this Ghrita are Shatahwa, Nalada, Kakoli, Ksheerakakoli, Yashtimadhu, Prapoundarika, Sarala, Pippali, Devadaru. It's prepared by classical method of Ghrita kalpana.

Aim: To prepare and do the physio-chemical study of finished product.

Materials and Methods: Shatahwadi ghrita is a polyherbal formulation which is formulated by classical method of Ghrita paka. It contains drugs having properties such as Tridoshahara, Chakshushya and Rasayana.

Results: Standardization of Shatahwadi ghrita shows remarkable results regarding Refractive index, saponification value, iodine value, peroxide value etc.

Conclusion: The prepared Shatahwadi ghrita matches the physicochemical parameters and can impact good therapeutic impact.

Keywords: Shatahwadi Ghrita, Analytical study

\section{INTRODUCTION}

Ayurveda is one of the world's oldest holistic healing systems. It came into existence more than 3000 years ago in India. According to Ayurveda for a person to be in Swastha (healthy)state his or her Doshas must be in a balanced state and the tissues and Malas work in a normal state ${ }^{1}$. The sensory and motor organs and 
mind, Atma must be also in pleasant state, so in order to attain this Ayurveda has described various forms of medicine such as Churna, Guti, Vati, Ghrita Paka, Taila paka, Lepa, Asava, Arishta etc. Sneha kalpana is a group of products prepared in the form of medicated Taila and Ghrita. Classically these formulations are having a longer shelf life in comparison to other Ayurvedic herbal medication form. It's the only Kalpana amongst the four Kalpanas which is used through all four modes of administration i.e. Pana, Abhyanga, Nasya \& Basti. ${ }^{2}$ Ghrita kalpana is a kind of formulation which is processed in a manner that both lipid soluble and water soluble active principles of the drugs are transferred into Ghrita. Shatahwadi Ghrita is a polyherbal formulation which is formulat- ed according to classical Ghrita Kalpana method ${ }^{3}$. It mainly contains Chakshushya, Tridoshahara and $R a$ sayana drugs.

\section{Aim and Objective}

- Analytical standardization of Shatahwadi Ghrita.

- To carry out physio -chemical analysis of Shatahwadi Ghrita.

\section{Material and Methods}

Collection of Raw Materials: The raw drugs for the study were procured from the hans pharmacy, Premnagar Ashram, Haridwar, Uttarakhand. The final product that is Shatahvadi Ghrita was prepared in Hansa Pharmacy, Sidcul, Haridwar, Uttarakhand. The ingredients were identified by PG Department of Dravyaguna, Rishikul campus, Haridwar.
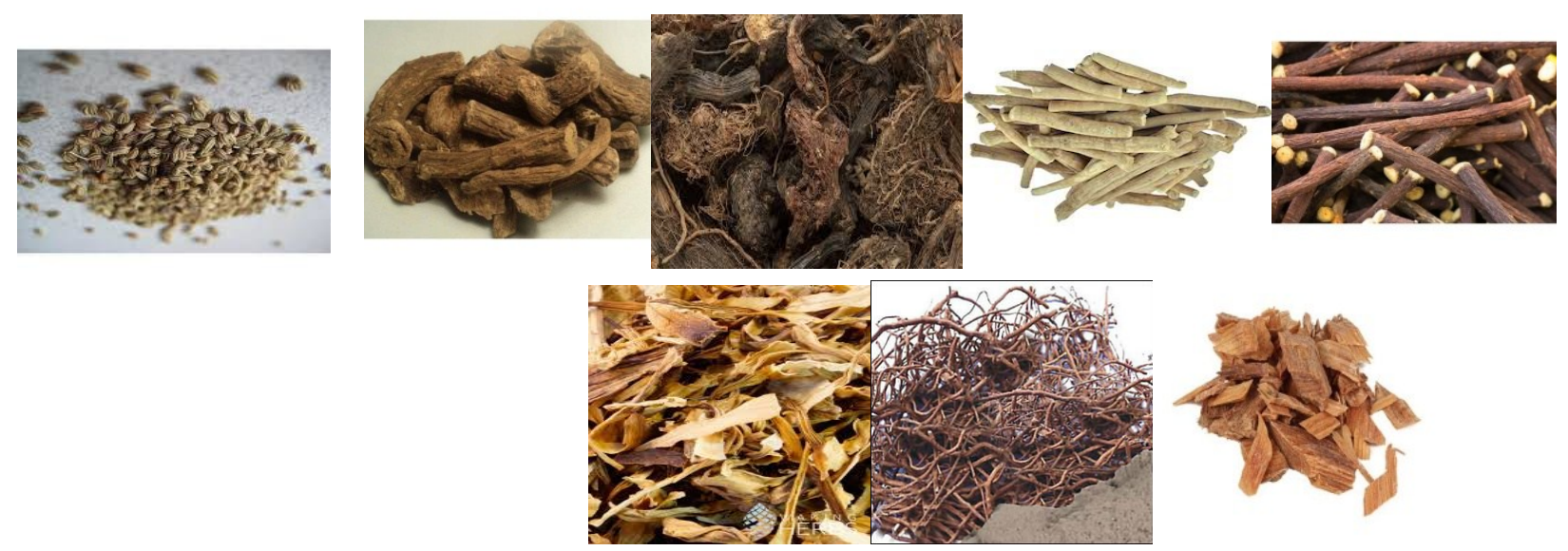

\section{Method of Preparation of Shatahwadi Ghrita}

The Shatahwadi Ghrita was prepared by classical method of Ghrita paka.

Ingredients of Shatahwadi Ghrita

Powders of Shatapushpa (Anethum sowa), Kusta (saussurea lappa), Jatamamsi (nardostachys jatamamsi), Aswagandha (Withania somnifera), Yastimadhu (glyccerhiza glabra), Prapoundarika (saccharum officinarum), Sarala (pinus roxburghii), Pippali (piper longum), Devadaru (cedrus deodar)200gms each

- Cow's ghee-5 kg

- Cow's milk-40litres

- Water -20 litres
To get final product, the contents were subjected to heat till up to Sneha siddhi lakshana were observed. Heating was stopped when Varti was formed and froth subsided. Varti was tested for absence of crackling sound. Ghrita was filtered while still hot (approx. 80 $0^{\circ}$ ) through a muslin cloth and allowed to cool. After that, the Ghrita was packed tightly in glass containers to protect from light and moisture.

\section{The Pharmacodynamics of Shatahwadi Ghrita}

The mode of action of a drug and its physiological effect can be best understood by the properties of its basic physiochemical factors i.e. Rasa, Guna, Veerya, Vipaka, Karma and Prabhava of the drugs. These properties affect the Doshas and determine their Doshkarma activity which in turn corrects the vitiated 
Doshas and maintain the Doshika equilibrium of the body.

Analytical Study: Prepared final product (Shatahwadi Ghrita) were analysed by employing various analytical parameters.

Organoleptic study: Organoleptic characteristics for various sensory characters like colour, taste, odour etc and was carefully noted down [10] [Table no.1]

Physiochemical analysis: Physiochemical analysis such as Acid value, Peroxide value, Saponification value, Iodine value, Refractive index, tests were carried out. [Table no 2]

Shatahwadi Ghrita was further subjected to thin layer chromatography (TLC) study.
TLC Profile Instrument used was Silica plate. The stationary phase used was TLC plate's silica gel F254 and mobile phase was Toluene: Ethyl acetate (90:10). The plate was sprayed with vanillinsulphuric acid reagent and the spots were detected after heating at $105^{\circ} \mathrm{C}$ for $10 \mathrm{~min}$. Rf value of each spot was recorded. Heavy Metal Analysis: Heavy metal analysis reveals Lead, Cadmium, Arsenic, Mercury mentioned [13] in [Table no.3]

Microbiological limit test: Microbial load estimation shows total bacterial count and total Yeast and mould count. Test for another specific pathogen is negative defined in [Table no.4]

Table 1: Organoleptic parameters of Shatahwadi Ghrita

Properties

\section{Colour}

Odour

Touch

Taste

Appearance

\section{Shatahwadi Ghrita}

Yellow

Pleasant

Unctuous

Bitter

Light

Table 2: Physio - chemical parameters of analysis

\begin{tabular}{|l|l|}
\hline Parameters & Shatahwadi Ghrita \\
\hline Refractive index & 1.4742 \\
\hline Weight & 0.899 \\
\hline Pcid value & 1.35 \\
\hline Saponification value & 2.76 \\
\hline Iodine value & 182.35 \\
\hline
\end{tabular}

Thin Layer Chromatography (TLC): Thin layer chromatography study (TLC) was carried out fewer than 254 and $366 \mathrm{~nm}$ UV to established finger printing profile. It showed Rf values $0.823,0.753,0.647$ which may be responsible for expression of its pharmacological and clinical actions.

Table 3: Heavy metal analysis

\begin{tabular}{|l|l|}
\hline Heavy Metal & Result \\
\hline Lead & $2.1 \mathrm{ppm}$ \\
\hline Cadmium & $<0.50 \mathrm{ppm}$ \\
\hline Arsenic & 0.08 \\
\hline Mercury & 0.24 \\
\hline
\end{tabular}


Table 4: Microbial load estimation of formulated Ghrita

\begin{tabular}{|l|l|}
\hline Total bacterial count $(\mathrm{cfu} / \mathrm{g})$ & $<10$ \\
\hline Total fungal count $(\mathrm{cfu} / \mathrm{g})$ & $<10$ \\
\hline E.coli & Absent \\
\hline Salmonella SP & Absent \\
\hline Pseudomonas aeroginosa & Absent \\
\hline Staphylococcus aureus & Absent \\
\hline
\end{tabular}

\section{DISCUSSION}

Physico-Chemical parameters: Refractive Index- It is the ratio of the velocity of light in a vacuum to its velocity in the substance. It is a fundamental physical property of a substance often used to identify a particular substance, confirm its purity, or measure its concentration. More will be Refractive Index, there will be more concentration of light which facilitates rancidification of Ghrita i.e. decomposition of Ghrita. Refractive index of the Shatahwadi Ghrita was 1.4742 .

Acid Value - It is a measure of the amount of Carboxylic acid groups in a chemical compound, such as fatty acid, or in a mixture of compounds as oil fats rancidify, triglycerides are converted into fatty acids and glycerol, causing an increase in acid. Less acid value denotes the less chance of decomposition of Ghrita thus increasing both life span and therapeutic value. The acid value of the Shatahwadi Ghrita was 1.35

Saponification Value - Saponification value gives an idea about the molecular weight of an oil / Fat. The saponification value and molecular weight of oil are inversely proportion. It is helpful in determining adulteration of given fat by one of the lower or higher saponification value. Saponification value of the Shatahwadi Ghrita was 182.35

Iodine Value - It indicates the degree of unsaturation. Greater degree of unsaturation indicates the possibility of the ghee becoming rancid due to atmospheric oxidation. And the iodine value of the Shathawadi Ghrita was 33.51

Peroxide Value - it is the most widely used analytical method. It gives a measure of the extent to which an oil/ghee sample as undergone primary oxidation; extent of secondary oxidation may be determined from p-anisidine test. Peroxide value of Shatahwadi Ghrita is 2.76

\section{CONCLUSION}

Physical test indicates Shatahwadi Ghrita is yellowish in colour with bitter taste and characteristic odour. Quantitative chemical analysis shows that in Shatahwadi Ghrita, Refractive index-1.4742, Acid value1.35 , Peroxide value- 2.76 , Saponification value182.35, Iodine value-33.51. TLC study of Shatahwadi Ghrita represents the presence of various ingredients in the sample and there is not any degradation in the final product. It acts as the fingerprint of the used sample, which can be used as the reference for the preparation of same kind of Ghrita.

\section{REFERENCES}

1. Maharishi Sushrut, Sushrut Samhita Uttartantra, Ayurved Tatva Sandipika Commentary Byshri Ambika Dutta Shastri, Varanasi, Chaukhambha Sanskrit Sansthan, Reprint Edition (2012),84 P.

2. Sharangdhar, Sharangdhar Samhita Uttara Khand, Jiwanprada Commentary of Dr. Smt. Shailaja Shrivastava, Varanasi Chaukhamba Oriantalia. Reprint Edition (2017), 189 P.

3. Vagbhata, Ashtanga Hrdayam Uttaratantra, Sasilekha Commentary By Prof. Shri. K. R. Shrikanta Murthy, Varanasi, Chaukhamba Krishnadas Academy, Reprint Edition (2015),123 P.

\section{Source of Support: Nil}

\section{Conflict of Interest: None Declared}

How to cite this URL: Radhika Menon et al: Analytical Study Of Shatahwadi Ghrita. International Ayurvedic Medical Journal \{online\} 2020 \{cited September, 2020\} Available from:

http://www.iamj.in/posts/images/upload/4381_4384.pdf 